\title{
Penggunaan Model Pembelajaran Group Investigation dengan Metode Latihan Terbimbing untuk Meningkatkan Prestasi Belajar Matematika
}

\section{Ni Nyoman Pusparini*}

SD Negeri 4 Abianbase

\author{
A R T I C L E I N F O \\ Article history: \\ Received 12 February \\ 2020 \\ Received in revised form \\ 18 March 2020 \\ Accepted 30 April 2020 \\ Available online 27 May \\ 2020 \\ Kata Kunci: \\ Group Investigation, \\ Metode Latihan \\ Terbimbing, Prestasi \\ Belajar \\ Keywords: \\ Group Investigation \\ Guided Training Method, \\ Learning Achievement
}

\begin{abstract}
A B S T R A K
Penelitian ini dilaksanakan di SD Negeri 4 Abianbase dengan tujuan untuk meningkatkan prestasi belajar Matematika siswa kelas V SD Negeri 4 Abianbase melalui penerapan pembelajaran Group Investigation dengan metode latihan terbimbing. Subjek penelitian ini adalah siswa kelas V SD Negeri 4 Abianbase yang berjumlah 20 orang, dalam mata pelajaran Matematika . Data tentang prestasi belajar siswa diperoleh dengan menggunakan metode tes dengan instrumanya yaitu berupa tes prestasi belajar. Data tersebut kemudian dianalisis dengan menggunakan teknik analisis deskriptif kuantitatif. Hasil penelitian ini adalah sebagai berikut (1) penerapan pembelajaran Group Investigation dengan metode latihan terbimbing dapat meningkatkan prestasi belajar Matematika siswa kelas V pada semester II SD Negeri 4 Abianbase tahun pelajaran 2017/2018. Skor rata-rata prestasi belajar siswa menunjukkan adanya peningkatan dari siklus I ke siklus II. Rata-rata kelas prestasi belajar pada awal pembelajaran hanya mencapai 60,50 siklus I meningkat menjadi 70,00 pada siklus II menjadi 79,00. Ketuntasan klaksikal awal hanya mencapai $30,00 \%$, pada siklus I meningkat menjadi $75,00 \%$ dan pada siklus II menjadi $90,00 \%$.
\end{abstract}

\section{A B S T R A C T}

This research was conducted at Abianbase 4 Elementary School with the aim to improve the mathematics learning achievement of the fifth grade students of Abianbase 4 Elementary School through the application of Group Investigation learning with the guided training method. The subjects of this study were 20th grade students of SD Negeri 4 Abianbase, in Mathematics. Data about student achievement is obtained using the test method with the instrument in the form of a learning achievement test. The data is then analyzed using quantitative descriptive analysis techniques. The results of this study are as follows (1) the application of Group Investigation learning with the guided training method can improve the mathematics learning achievement of fifth grade students in semester II of SD Negeri 4 Abianbase in the academic year 2017/2018. The average score of student achievement shows an increase from cycle I to cycle II. The average grade of learning achievement at the beginning of learning only reached 60.50 the first cycle increased to 70.00 in the second cycle to 79.00. Initial claxical completeness only reached $30.00 \%$, in the first cycle increased to $75.00 \%$ and in the second cycle became $90.00 \%$. 


\section{Pendahuluan}

Prestasi belajar adalah sebuah perubahan yang dihasilkan dari proses belajar yang mana perubahan yang terjadi bukan hanya pengetahuan saja melainkan psikomotor dan efektifnya juga. Menurut Nasution (1996) prestasi belajar adalah kemampuan yang dicapai dalm aspek kognitif, psikomotor serta efektif. Menurut Suryabrata (2002) menyatakn bahwa prestasi belajar adalah hasil yang diapai dari latihan, pengalaman yang dilakukan seacara sadar, prestasi belajar hasil dari perubahan dalam proses belajar. Presatasi bealajar adalah tingkat keberhasilan siswa dalam mencapai tujuan pembelajaran yang sudah di programkan dalam proses pembelajaran. (Syah, 2011; Dimyati dan Mudjiyono, 2009; dan Tohirin, 2008). Sedangkan Wijaya, (2005) menyatakan bahwa kemampuan yang dimiliki oleh siswa setelah memperoleh pengelaman belajar, capain prestasinya adalah kognitif, psikomotorik, serta afektif. Tercapainya prestasi belajar yang baik sangatdipengaruhi oleh dua faktor yaitu 1) faktor internal yang berupa faktor jasmani (kesehata/ cacat tubuh), faktor psikologis (intelegensi, perhatian, minat, bakat, motivasi, kematangan, dan kesiapan), faktor kelelahan. 2) faktor eksterna adalah faktor yang berasal dari luar diri siswa antara lain faktor keluarga (ekonomi kelauragam latar belakang budayam relasi keluargam suasana rumah dan lain-lain), faktor sekolah (metode mengajar guru, kurikulum, lingkungan sekolah, hubungan guru dan siswa atau siswa dengan siswa dan lain), faktor lingkungan masyarakat (teman bergaul, bentuk kebudayaan masyarakat) (Slamato, 2010). Jadi, prestasi belajar adalah kemapuan-kemapuan yang diperoleh melalui proses belajar. Prestasi belajar akan dipengaruhi oleh faktor internal dan faktor eksternal.

Seperti yang sudah dijabarkan presatasi belajar siswa sangat dipengaruhi oleh faktor internal dan faktor ekternal. Kedua faktor ini saling berhubungan satu sama lain. untuk mengabangkan faktor internal seoarang anak, guru sangat berperan penting untuk menciptakan suasana belajar yang aktif dan bermakna. Tentunya hal ini tidak terlepas dari kemapuan guru dalam merancang proses pembelajaran, belajar akan bermakna apabila pembelajaran itu sebagai subjek dan objek belajar, maksudnya adalah pembelajaran harus membuat siswa aktif membangun pengetahuanya sendiri, pusat belajar siswa bukannya guru serta tentunya guru sangat berperan didalamnya. Pada mata pelajaran Matematika yang menuntut begitu banyak pencapaian konsep sehingga mengakibatkan motivasi belajar kurang baik. Motivasi belajar dapat dipengaruhi oleh faktor internal yaitu kemampuan yang berasal dari siswa,yang meliputi kecerdasan, bakat, minat, motivasi dan emosi. Dan juga dipengaruhi oleh faktor eksternal berasal dari luar, meliputi lingkungan keluarga, sekolah, dan masyarakat.

Namun dilapangan masih banyak kelemahan guru di dalam melaksanakan proses pembelajaran. Guru hanya bercerita di kelas dengan deskripsi yang kurang jelas tentang materi pembelajaran. Guru kurang memberikan kesempatan kepada siswa untuk berkembang sesuai dengan kemampuannya. Pembelajaran selalu berpusat pada guru sehingga siswa menjadi fasif atau kurang aktif. Pada akhirnya siswa kurang termotivasi untuk belajar sehingga kecerdasan siswa tidak sesuai dengan apa yang diharapkan. Menyadari permasalahan yang sedang dihadapi, untuk mendukung semua yang telah dijelaskan di atas. Guru selaku peneliti yang bertugas di SD Negeri 4 Abianbase mencoba melakukan koreksi dan refleksi atas prestasi belajar awal siswa kelas V semester II tahun pelajaran 2017/2018 yang ditemukan pada saat observasi. Rata-rata nilai pembelajaran matematika siswa yang diperoleh hanya mencapai 60,50 dengan prosentase ketuntasan belajar sebesar 30,00\%. Nilai tersebut ternyata masih jauh dari Kriteria Ketuntasan Minimal (KKM) yang ditetapkan sekolah. Persoalannya, bukan hanya karena kemampuan siswa yang rendah, namun perlu dikaji faktor yang paling mendasar dalam mempengaruhi rendahnya prestasi belajar siswa. Berdasarkan hal tersebut teridentifikasi masalah seperti ; (1) rendahnya prestasi belajar Matematika, (2) strategi guru dalam membelajarkan siswa masih belum optimal, (3) guru kurang menguasai model pembelajaran yang inovatif dan kreatif.

Melihat hal tersebut dipandang perlu dilakukan upaya perbaikan pembelajaran khususnya mata pelajaran Matematika di kelas V SD Negeri 4 Abianbase. Guru sebagai tenaga professional hendaknya dapat melaksanakan dan mewujudkan tujuan pendidikan nasional yang telah ditetapkan oleh pemerintah melalui Undang-Undang. Guru hendaknya dapat melaksanakan proses pembelajaran yang dapat menghasilkan output yang bermutu sesuai harapan pemerintah dan harapan masyarakat. Dengan demikian dari waktu ke waktu harus dicermati guru agar kualitasnya terus meningkat.Untuk mengatasi persoalan tersebut maka akan dilakukan penelitian sebagai solusi dan memecahkan permasalahan. Untuk mengotimalkan prestasi belajar siswa, perlu diadakan situasi pembelajaran yang menyenangkan dan merangsang minat siswa untuk lebih antusias berperan aktif dalam proses pembelajaran. Untuk mengetahui perubahan ke arah yang lebih baik dipandang perlu dilakukan Penelitian. Pada penelitian ini model pembelajaran kooperatif Group Investigation berbantuan metode latihan terbimbing.

Model pembelajaran kooperatif tipe group investigation adalah salah satu model kooperatif yng kegiatannya dilkukan pada kelempok kecil yang heterogen, dimana siswa akan dilibatkan dalam 
menentukan topik maupun cara memecahkannya melalui investigasi, sehingga siswa mampu mengembangakan kemampuanya terhadap materi. (Agus, 2015). Sedangkan menurut putri (2018) menyatakan bahwa model pembelajaran kooperatif tipe GI adalah model pembelajaran yang mengebangkan kemampuan penalaran matematis siswa. Pembelajaran dengan model kooperatif tipe GI meruapak model yang konplek yang memadukan antara prinsip kelompok/ kerjasama dengan pembelajaran kontruktivisme. (Een, Hardianto1, dan Lusi Eka Afri, 2015). Model ini mempunyai keunikan dibandingkan dengan model kooperatif yang lainnya dimana model ini melibatkan kemapuan siswa dalam mempelajari matematika melalui penyelidikan. Investigasi dilkukan melalui mengumpulkan data, informasi, fakta, percobaan yang bertujuan untuk mendapatkan pemecahan atas masalah yang diberikan. Proses penyedikan berasal dari pernyataan yang siswa buat sendiri, sumber-sumber yang siswa temukan dan cari sendiri, serta jawabab yang mereka temukan. Dengan adanya proses investigasi ini siswa akan memukan dan membangun pengetahunnya sendiri, sehingga siswa akan dimotivasi untuk belajar aktif dan lebih bermakna. ((Een, Hardianto1, dan Lusi Eka Afri, 2015). Model kooperatif tipe GI mempunyai kelebihan dibandingkan model kooperatif menurut Sharan (dalam Sumarmi, 2012:127) lainya yaitu: 1) siswa melakukankegiatan berdiskusi dan menyumbangkan ide tertentu, 2) gaya bicara dan kerjasama siswa dapat diobservasi, 3) siswa dapat belajar kooperatif lebih efektif, dengan demikian dapat meningkatkan interaksi sosial mereka, 4) GI dapat mendorong siswa untuk berpartisipasi aktif, sehingga pengetahuan yang diperoleh dapat ditransfer ke situasi diluar kelas, 5) GI mengijinkan guru untuk lebih informal, 6) GI dapat meningkatkan penampilan dan prestasi belajar siswa.

Banyak penelitian yang sudah dilakukan, yang berkatan dengan model ini, yangberpengaruh positif, peneleitian tersebut antara lain: penelitian yang dilkukan Nunung dan Rachmawati, 2018 menyatakan bahwa model Group Investigation dengan AfL menghasilkan hasil belajar matematika yang lebih baik daripada model Group Investigation, model Group Investigation dengan AfL menghasilkan hasil belajar matematika lebih baik daripada model pembelajaran langsung, dan model Group Investigation menghasilkan hasil belajar matematika yang lebih baik daripada model pembelajaran langsung. Oleh karena itu, dapat disimpulkan model Group Investigation dengan AfL menghasilkan hasil belajar matematika yang lebih baik daripada model Group Investigation dan model pembelajaran langsung. Penelitian yang dilakukan oleh Widiantara, Sedanayasa, dan Dibia (2013) model pembelajaran kooperatif tipe Group Investigation (GI) berbantuan media realita berpengaruh terhadap hasil belajar matematika siswa kelas IV Sekolah Dasar Gugus VI di Kelurahan Kampung Baru Kecamatan Buleleng, Kabupaten Buleleng tahun pelajaran 2012/2013. Sedangkan menurut (Achmad Taher, Sugeng Utaya, dan Syamsul Bachri (2019) menyatakan model Group Investigation (GI) berpengaruh terhadap hasil belajar Geografi topik abrasi pantai di Pulau Kangean. Pada kelas eksperimen yang diajar dengan model pembelajaran Group Investigation (GI) memperoleh nilai rata-rata gain score yang lebih tinggi dibanding dengan kelas kontrol yang diajar dengan metode diskusi. Hal ini disebabkan siswa yang melakukan investigasi dapat memahami materi pembelajaran Geografi topik abrasi pantai lebih baik dibanding siswa yang belajar secara konvensional.

Sedangkan metode latihan adalah metode yang memberikan kesempatan kepada siswa untuk berlatih memberikan suatu keterampilan yang tertentu. Terbimbing di sini artinya proses belajar mengajar yang dibimbing berdasarkan petunjuk dan penjelasan guru. Melalui metode ini dapat dikembangkan keterampilan melalui pembiasaan (Aqib, 2002: 97). Metode latihan memiliki kelebihan (Sagala, 2005: 217-218), yaitu: 1) Pembentukan kebiasaan yang dilakukan dengan menggunakan metode ini akan menambah ketepatan dan kecepatan pelaksanaan. 2) Pemanfaatan kebiasaan-kebiasaan tidak memerlukan banyak kosentrasi dalam pelaksanaannya. 3) Pembentukan kebiasaan membuat gerakangerakan yang kompleks, rumit menjadi otomatis.

Berdasarkan pemaparan di atas, maka dalam penelitian ini akan mengambil judul tentang Penggunaan Model Pembelajaran Group Investigation Dengan Metode Latihan Terbimbing Untuk Meningkatkan Prestasi Belajar Matematika Siswa Kelas V Semester II SD Negeri 4 Abianbase Tahun Pelajaran 2017/2018.

\section{Metode}

Penelitian ini dilaksanakan di SD Negeri 4 Abianbase dalam pembelajaran Matematika pada semester II tahun pelajaran 2017/2018. Subjek penelitian ini adalah siswa kelas V yang berjumlah 20 siswa. Penelitian ini menggunakan rancangan penelitian tindakan kelas (PTK) atau classroom action research. Dikatakan demikian karena penelitian ini dilaksanakan di dalam kelas dengan menerapkan tindakan yang disengaja. Ini sesuai dengan pengertian penelitian tindakan kelas, yaitu merupakan suatu pencermatan terhadap kegiatan belajar berupa sebuah tindakan yang sengaja dimunculkan dan terjadi dalam sebuah kelas secara bersamaan (Arikunto, dkk, 2006:3).Sementara itu, (Kunandar, 2011:46) 
mengemukakan bahwa penelitian tindakan kelas adalah suatu kegiatan ilmiah yang dilakukan oleh guru di kelasnya sendiri. Jadi dapat dikatakan bahwa penelitian tindakan kelas (PTK) adalah suatu pencermatan yang dilakukan di kelas dengan melakukan suatu tindakan untuk menyelesaikan masalah yang dihadapi guru dalam kegiatan pembelajaran.

Terdapat empat tahapan yang harus dilaksanakan, meliputi merancang atau merencanakan, melaksanakan atau melakukan tindakan, mengamati atau evaluasi, dan refleksi.

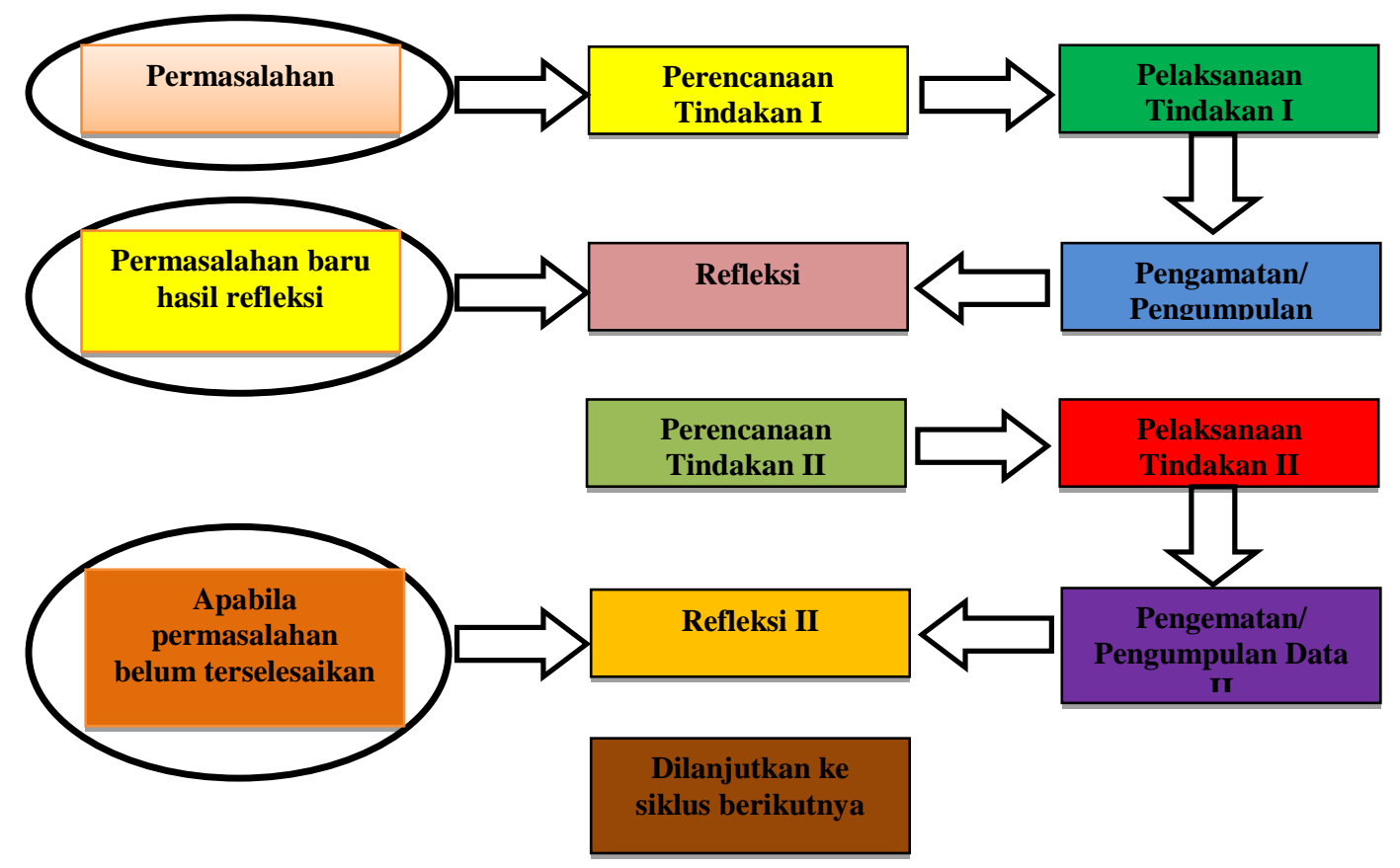

Gambar 1. Penelitian Tindakan Model Arikunto, Suharsimi, 2007

Pada tahap ini peneliti membuat RPP, berkonsultasi dengan teman sejawat membuat instrumen. Pada tahap menyusun rancangan diupayakan ada kesepakatan antara guru dan sejawat. Rancangan dilakukan bersama antara peneliti yang akan melakukan tindakan dengan guru lain yang akan mengamati proses jalannya tindakan. Hal tersebut untuk mengurangi unsur subjektivitas pengamat serta mutu kecermatan pengamatan yang dilakukan.

Tahap pelaksanaan tindakan dilakukan dengan pembelajaran di kelas. Pada tahap ini guru peneliti giat melakukan tindakan menggunakan model pembelajaran Group Investigation dengan metode latihan terbimbing. Rancangan tindakan tersebut sebelumnya telah dilatih untuk dapat diterapkan di dalam kelas sesuai dengan skenarionya. Skenario dari tindakan diupayakan dilaksanakan dengan baik dan wajar.

Tahap ini sebenarnya berjalan bersamaan dengan saat pelaksanaan. Pengamatan dilakukan pada waktu tindakan sedang berjalan, jadi, keduanya berlangsung dalam waktu yang sama. Pengamatan juga dilakukan setelah kegiatan selesai yaitu pada saat diadakan kegiatan tes. Guru memperhatikan proses yang sedang berlangsung, memperhatikan keaktifan siswa dan guru menilai sikap siswa saat menjawab soal.

Pada tahap ini, guru yang bertindak sebagai peneliti melakukan pengamatan dan mencatat semua hal yang diperlukan dan terjadi selama pelaksanaan tindakan berlangsung. Pengumpulan data ini dilakukan dengan menggunakan tes prestasi belajar yang telah tersusun, termasuk juga pengamatan secara cermat pelaksanaan skenario tindakan dari waktu ke waktu serta dampaknya terhadap proses dan prestasi belajar siswa.

Tahapan ini dimaksudkan untuk mengkaji secara menyeluruh tindakan yang telah dilakukan, berdasarkan data yang telah terkumpul, kemudian dilakukan evaluasi guna menyempurnakan tindakan berikutnya. Refleksi dalam PTK mencakup analisis, sintesis, dan penilaian terhadap hasil pengamatan atas tindakan yang dilakukan. Jika terdapat masalah dari proses refleksi maka dilakukan proses pengkajian ulang melalui siklus berikutnya yang meliputi kegiatan: perencanaan ulang, tindakan ulang, dan pengamatan ulang sehingga permasalahan dapat teratasi Tehnik pengumpulan data yang digunakan dalam peneltian tindakan kelas ini adalah sebagai berikut: Teknik tes. Penelitian ini juga menggunakan metode tes sebagai metode untuk mengumpulkan data. Menurut Nurkancana dan Sunartana (1990:34) menyatakan bahwa, "Tes adalah suatu cara untuk mengadakan penilaian yang berbentuk suatu tugas atau 
serangkaian tugas yang harus dikerjakan oleh anak atau sekelompok anak sehingga menghasilkan suatu nilai tentang tingkah laku atau prestasi anak tersebut, yang dapat dibandingkan dengan nilai yang dicapai oleh anak-anak lain atau dengan nilai standar yang ditetapkan". Ahli lain mengemukakan pengertian tes sebagai alat penilaian yang terdiri dari pertanyaan-pertanyaan yang diberikan kepada siswa untuk mendapat jawaban dari siswa dalam bentuk lisan (tes lisan), dalam bentuk tulisan (tes tulisan), atau dalam bentuk perbuatan (tes tindakan) (Sudjana, 2010:35). Sedangkan Kunandar (2011:186) mengemukakan bahwa,

"tes adalah sejumlah pertanyaan yang disampaikan pada seseorang atau sejumlah orang untuk mengungkapkan keadaan atau tingkat perkembangan salah satu atau beberapa aspek psikologis di dalam dirinya. Aspek psikologis itu dapat berupa prestasi belajar atau prestasi belajar, minat, bakat, sikap, kecerdasan,reaksi motorik, dan berbagai aspek kepribadian".

Sesuai dengan dua pendapat di atas, maka dapat disimpulkan bahwa tes adalah cara penilaian dalam bentuk tugas yang harus dikerjakan oleh perseorangan atau kelompok untuk mengungkapkan keadaan atau tingkat perkembangan salah satu atau beberapa aspek psikologis di dalam dirinya.

Dalam penelitian ini aspek yang di tes adalah prestasi belajar Matematika siswa. Tes yang digunakan adalah tes tertulis. Tes tertulis merupakan tes dimana soal dan jawaban yang diberikan kepada siswa dalam bentuk tulisan (Kunandar, 2011:187). Bentuk tes yang digunakan adalah esay. Dengan jumlah 5 butir yang dibuat sendiri berdasarkan SK dan KD yang tersedia pada kurikulum.

\section{Hasil dan Pembahasan}

Data awal yang diperoleh dengan rata-rata 60,50 menunjukkan bahwa kemampuan siswa dalam mata pelajaran Matematika masih sangat rendah mengingat kriteria ketuntasan belajar siswa untuk mata pelajaran ini di SD Negeri 4 Abianbase adalah 70,00. Dengan nilai yang sangat rendah seperti itu maka peneliti mengupayakan untuk dapat meningkatkan prestasi belajar anak/siswa menggunakan metode/model pembelajaran Group Investigation dengan metode latihan terbimbing. Akhirnya dengan penerapan metode/model pembelajaran Group Investigation dengan metode latihan terbimbing yang benar sesuai teori yang ada, peningkatan rata-rata prestasi belajar anak/siswa pada siklus I dapat diupayakan dan mencapai rata-rata 70,00. Namun rata-rata tersebut belum maksimal karena hanya 15 siswa memperoleh nilai di atas KKM sedangkan yang lainnya belum mencapai KKM. Sedangkan prosentase ketuntasan belajar mereka baru mencapai 75\%. Hal tersebut terjadi akibat penerapan model pembelajaran Group Investigation dengan metode latihan terbimbing belum maksimal dapat dilakukan disebabkan penerapan model/metode tersebut baru dicobakan sehingga guru masih belum mampu melaksanakannya sesua alur teori yang benar.

Pada siklus ke II perbaikan prestasi belajar siswa diupayakan lebih maksimal dengan peneliti membuat perencanaan yang lebih baik, menggunakan alur dan teori dari metode/model penerapan model pembelajaran Group Investigation dengan metode latihan terbimbing dengan benar dan lebih maksimal. Peneliti giat memotivasi siswa agar giat belajar, memberi arahan-arahan, menuntun mereka untuk mampu menguasai materi pelajaran pada mata pelajaran Matematika lebih optimal. Akhirnya dengan semua upaya tersebut peneliti mampu meningkatkan prestasi belajar siswa pada siklus II menjadi ratarata 79,00 dengan presentase ketuntasan mencapai 90\%, hal ini menunjukkan terjadinya peningkatan yang sangat signifikan. Upaya-upaya yang maksimal tersebut menuntun pada suatu keberhasilan bahwa penerapan model pembelajaran Group Investigation dengan metode latihan terbimbing mampu meningkatkan prestasi belajar Matematika siswa kelas V SD Negeri 4 Abianbase pada semester II tahun pelajaran 2017/2018.

Semua hasil yang diperoleh dari awal, siklus I dan siklus II digambarkan dalam bentuk tabel dan grafik seperti berikut:

Tabel 1 . Tabel Data Prestasi Belajar Siswa Kelas V SD Negeri 4 Abianbase

\begin{tabular}{ccccll}
\hline DATA & AWAL & SIKLUS I & SIKLUS II & \multicolumn{2}{c}{ VARIABEL } \\
\hline Skor Nilai & 1210 & 1400 & 1580 & Prestasi & belajar \\
Rata Rata Kelas & 60,50 & 70,00 & 79,00 & Matematika & \\
Persentase & $30 \%$ & $75 \%$ & $90 \%$ & Dengan & \\
Ketuntasan & & & & & \\
\hline
\end{tabular}




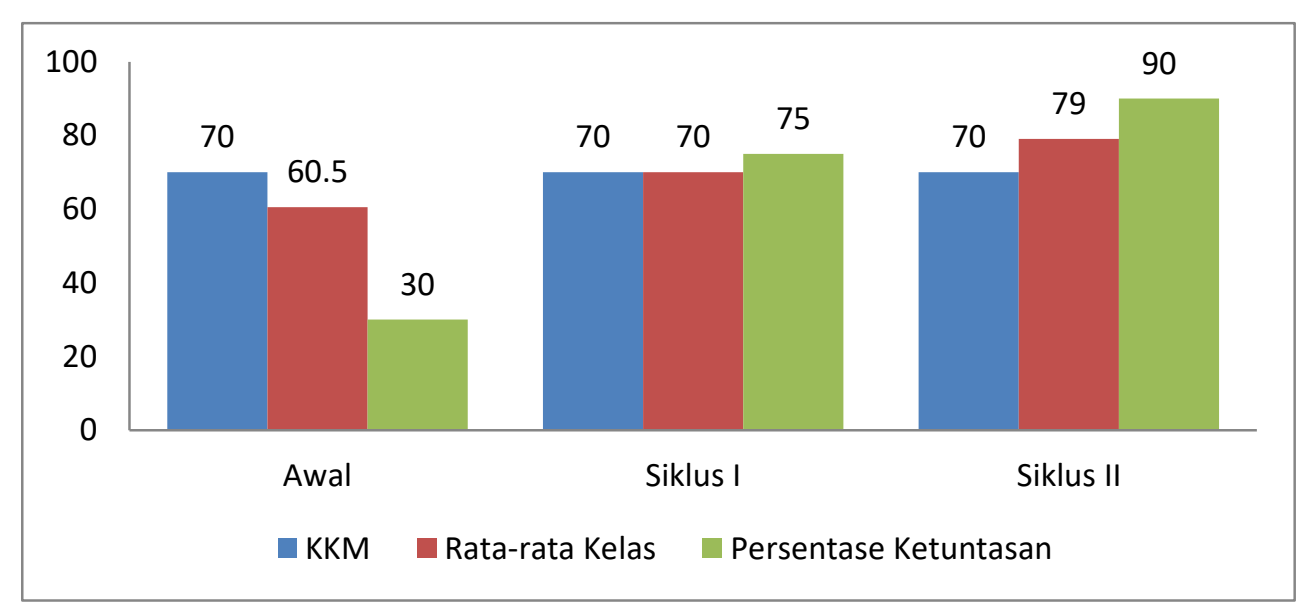

Gambar 1. Grafik Histogram Prestasi Belajar Matematika Siswa Kelas V SD Negeri 4 Abianbase Semester II Tahun Pelajaran 2017/2018

Berdasarkan hasil penelitian yang dilkukan maka dapat dikatakan bahwa terdapatpeningkatan presatasi belajar dari siklus I dan siklus II hal ini tidak terlepas dari penerapan model GI bermantuan Metode latihan terbimbing. Dimana model ini akan menumbuhkembangkan keaktifan siswa serta motivasi siswa. Salah satu tolak ukur bahwa suatu pembelajaran telah dicapai dapat dilihat dari prestasi belajar siswa. Djamarah (1994:23) mendefinisikan prestasi belajar sebagai hasil yang diperoleh berupa kesan-kesan yang mengakibatkan perubahan dalam diri individu sebagai hasil dari aktivitas dalam belajar.Kalau perubahan tingkah laku adalah tujuan yang mau dicapai dari aktivitas belajar, maka perubahan tingkah laku itulah salah satu indikator yang dijadikan pedoman untuk mengetahui kemajuan individu dalam segala hal yang diperolehnya di sekolah. Dengan kata lain prestasi belajar merupakan kemampuan-kemampuan yang dimiliki oleh siswa sebagai akibat perbuatan belajar atau setelah menerima pengalaman belajar, yang dapat dikatagorikan menjadi tiga ranah, yakni ranah kognitif, afektif, dan psikomotor.

Untuk meningkatkan prestasi belajar, dapat diterapkan model pembelajaran Group Investigation Dengan Metode Latihan Terbimbing. Berdasarkan penelitian yang telah dilakukan dengan menggunakan Group Investigation Dengan Metode Latihan Terbimbing didapatkan hasil sebagai berikut. Model pembelajaran kooperatif tipe group investigation adalah salah satu model kooperatif yng kegiatannya dilkukan pada kelempok kecil yang heterogen, dimana siswa akan dilibatkan dalam menentukan topik maupun cara memecahkannya melalui investigasi, sehingga siswa mampu mengembangakan kemampuanya terhadap materi. (Agus, 2015). Sedangkan menurut putri (2018) menyatakan bahwa model pembelajaran kooperatif tipe GI adalah model pembelajaran yang mengebangkan kemampuan penalaran matematis siswa. Pembelajaran dengan model kooperatif tipe GI meruapak model yang konplek yang memadukan antara prinsip kelompok/ kerjasama dengan pembelajaran kontruktivisme. (Een, Hardianto1, dan Lusi Eka Afri, 2015). Model ini mempunyai keunikan dibandingkan dengan model kooperatif yang lainnya dimana model ini melibatkan kemapuan siswa dalam mempelajari matematika melalui penyelidikan. Investigasi dilkukan melalui mengumpulkan data, informasi, fakta, percobaan yang bertujuan untuk mendapatkan pemecahan atas masalah yang diberikan. Proses penyedikan berasal dari pernyataan yang siswa buat sendiri, sumber-sumber yang siswa temukan dan cari sendiri, serta jawabab yang mereka temukan. Dengan adanya proses investigasi ini siswa akan memukan dan membangun pengetahunnya sendiri, sehingga siswa akan dimotivasi untuk belajar aktif dan lebih bermakna. ((Een, Hardianto1, dan Lusi Eka Afri, 2015). Model kooperatif tipe GI mempunyai kelebihan dibandingkan model kooperatif menurut Sharan (dalam Sumarmi, 2012:127) lainya yaitu: 1) siswa melakukankegiatan berdiskusi dan menyumbangkan ide tertentu, 2) gaya bicara dan kerjasama siswa dapat diobservasi, 3) siswa dapat belajar kooperatif lebih efektif, dengan demikian dapat meningkatkan interaksi sosial mereka, 4) GI dapat mendorong siswa untuk berpartisipasi aktif, sehingga pengetahuan yang diperoleh dapat ditransfer ke situasi diluar kelas, 5) GI mengijinkan guru untuk lebih informal, 6) GI dapat meningkatkan penampilan dan prestasi belajar siswa. Sedangkan metode latihan adalah metode yang memberikan kesempatan kepada siswa untuk berlatih memberikan suatu keterampilan yang tertentu. Terbimbing di sini artinya proses belajar mengajar yang dibimbing berdasarkan petunjuk dan penjelasan guru. Melalui metode ini dapat dikembangkan keterampilan melalui pembiasaan (Aqib, 2002: 97). Metode latihan memiliki kelebihan (Sagala, 2005: 217-218), yaitu: 1) Pembentukan kebiasaan yang dilakukan dengan 
menggunakan metode ini akan menambah ketepatan dan kecepatan pelaksanaan. 2) Pemanfaatan kebiasaan-kebiasaan tidak memerlukan banyak kosentrasi dalam pelaksanaannya. 3) Pembentukan kebiasaan membuat gerakan-gerakan yang kompleks, rumit menjadi otomatis.

Hasil penelitian ini sejalan dengan hasil penelitian yang dilakukan oleh Ayuwanti, pada tahun 2016 dengan judul Meningkatkan Aktivitas dan Hasil Belajar Matematika Menggunakan Model Pembelajaran Kooperatif Tipe Group Investigation di SMK Tuma'ninah Yasin Metro. Hasil penelitian menunjukkan bahwa: 1) Pembelajaran menggunakan model pembelajaran kooperatif tipe Group Investigation (GI) dapat meningkatkan aktivitas belajar matematika siswa kelas X SMK Tuma'ninah Yasin Metro. 2) Pembelajaran menggunakan model pembelajaran kooperatif tipe Group Investigation (GI) dapat meningkatkan hasil belajar siswa dengan rata-rata dari $27,5 \%$ siklus I menjadi $54,54 \%$ pada siklus II dan menjadi $81,81 \%$ pada siklus III. Selanjutnya penelitian yang dilakukan oleh Lestari pada tahun 2017 dengan judul Penerapan Pembelajaran Group Investigation untuk Meningkatkan Prestasi dan Keaktifan Siswa Materi Statistika. Hasil penelitian ini menunjukkan bahwa kinerja guru dan aktivitas siswa telah memenuhi indikator dengan pelaksanaan PTK selama 2 siklus, sedangkan hasil belajar siswa dan prosentase ketuntasan 100\% tercapai dengan penerapan PTK selama 3 siklus. Jadi, Group Investigation direkomendasikan untuk diterapkan dalam pembelajaran matematika karena dapat meningkatkan prestasi dan keaktifan siswa khususnya pada pembelajaran statistika. Penelitian yang dilkukan Nunung dan Rachmawati, 2018 menyatakan bahwa model Group Investigation dengan AfL menghasilkan hasil belajar matematika yang lebih baik daripada model Group Investigation, model Group Investigation dengan AfL menghasilkan hasil belajar matematika lebih baik daripada model pembelajaran langsung, dan model Group Investigation menghasilkan hasil belajar matematika yang lebih baik daripada model pembelajaran langsung. Oleh karena itu, dapat disimpulkan model Group Investigation dengan AfL menghasilkan hasil belajar matematika yang lebih baik daripada model Group Investigation dan model pembelajaran langsung. Penelitian yang dilakukan oleh Widiantara, Sedanayasa, dan Dibia (2013) model pembelajaran kooperatif tipe Group Investigation (GI) berbantuan media realita berpengaruh terhadap hasil belajar matematika siswa kelas IV Sekolah Dasar Gugus VI di Kelurahan Kampung Baru Kecamatan Buleleng, Kabupaten Buleleng tahun pelajaran 2012/2013. Sedangkan menurut (Achmad Taher, Sugeng Utaya, dan Syamsul Bachri (2019) menyatakan model Group Investigation (GI) berpengaruh terhadap hasil belajar Geografi topik abrasi pantai di Pulau Kangean. Pada kelas eksperimen yang diajar dengan model pembelajaran Group Investigation (GI) memperoleh nilai rata-rata gain score yang lebih tinggi dibanding dengan kelas kontrol yang diajar dengan metode diskusi. Hal ini disebabkan siswa yang melakukan investigasi dapat memahami materi pembelajaran Geografi topik abrasi pantai lebih baik dibanding siswa yang belajar secara konvensional.

\section{Simpulan Dan Saran}

Penelitian Dari hasil refleksi yang telah disampaikan di Bab IV dan dengan melihat semua data yang telah dipaparkan, dapat ditemukan hal-hal sebagai berikut : 1) Dari data awal ada 14 siswa mendapat nilai dibawah KKM dan pada siklus I menurun menjadi 5 siswa dan siklus II hanya 2 siswa yang mendapat nilai di bawah KKM, 2) Nilai rata-rata awal 60,50 naik menjadi 70,00 pada siklus I dan pada siklus II naik menjadi 79,00, dan 3)

1. Dari data awal siswa yang tuntas hanya 6 orang sedangkan pada siklus I menjadi lebih banyak yaitu 15 siswa dan pada siklus II sebanyak 18 siswa mampu memperoleh nilai sandar/melampaui KKM.

Berdasarkan temuan tersebut, dapat disimpulkan bahwa: penggunaan model pembelajaran Group Investigation dengan metode latihan terbimbing secara efektif dapat meningkatkan prestasi belajar matematika siswa kelas V semester II SD Negeri 4 Abianbase tahun pelajaran 2017/2018.

Saran yang dapat disampaikan berdasarkan penelitian yang telah dilakukan adalah sebagai berikut. Siswa disarankan untuk selalu bersemangat dalam belajar, sehingga mampu menguasai pembelajaran dengan baik. Guru disarankan selalu menggunakan pembelajaran yang inovatif, sehingga siswa merasa senang dan bersemangat dalam belajar. Sekolah disarankan untuk selalu mendukung kegiatan pembelajaran dengan menyediakan sarana dan prasarana yang lengkap. Peneliti lain disarankan untuk menggunakan penelitian ini sebagai rujukan atau pedoman dalam melakukan penelitian selanjutnya.

\section{Daftar Rujukan}

Abdurrahman, Mulyono. 1999. Pendidikan bagi Anak Berkesulitan Belajar.Jakarta: Rineka Cipta.

Arends, Richard I. 2004. Learning to Teach. Sixth Edition. New York: McGraw-Hill 
Arikunto, Suharsimi dkk.2006. Penelitian Tindakan Kelas. Jakarta: Bumi Aksara.

Arikunto, Suharsimi. 2007. Prosedur Penelitian Suatu Pendekatan Praktek. Jakarta: Rineka Cipta.

Aqib, Zainal. 2002. Profesionalisme Guru dalam Pembelajaran. Surabaya: Insan Cendikia.

Ayuwanti pada tahun 2016 dengan judul Meningkatkan Aktivitas dan Hasil Belajar Matematika Menggunakan Model Pembelajaran Kooperatif Tipe Group Investigation di SMK Tuma'ninah Yasin Metro. Jurnal of Mathematics Education IKIP Veteran Semarang Volume 1 Nomor 2.

Dimyati dan Mudjiyono.2009. Belajar dan Pembelajaran. Jakarta: Rineka Cipta.

Djamarah. 1994. Prestasi Belajar dan Kompetensi Guru. Surabaya: Usaha Nasional.

Een, Hardianto, dan Lusi Eka Afri2. 2015. Pengaruh Model Pembelajaran Kooperatif Tipe Group Investigation (GI) Terhadap Hasil Belajar Matematika Siswa Kelas Viii Smp Negeri 4 Rambah. https://www.neliti.com/id/publications/109866/pengaruh-model-pembelajaran-kooperatif-tipegroup-investigation-gi-terhadap-hasil

Kunandar. 2011. Langkah Mudah Penelitian Tindakan Kelas Sebagai Pengembangan Profesi Guru. Jakarta: Rajawali Pres.

Lestari pada tahun 2017 dengan judul Penerapan Pembelajaran Group Investigation untuk Meningkatkan Prestasi dan Keaktifan Siswa Materi Statistika. Jurnal SAP (Susunan Artikel Pendidikan) Unindra Volume 1 Nomor 2.

Nana Sudjana 2010. Dasar-dasar Proses Belajar. Bandung: Sinar Baru.

Nana Sudjana.2005. Dasar-dasar Proses Belajar Mengajar. Bandung: Sinar Baru Algesindo.

Putri, P. M. (2018). Strategi Group Investigation untuk Meningkatkan Kemampuan Penalaran Matematis Siswa SMA. JPPM Vol. 11 No.1, 83- 93.

Slameto.2010. Belajar dan Faktor-Faktor yang Mempengaruhinya. Jakarta: PT.Rineka Cipta. Hal. 54

Sobarningsih , Nunung dan Tika Karlina Rachmawati. 2018. Pengaruh Model Group Investigation Dan Model Group Investigation Dengan AFL Terhadap Hasil Belajar Matematika. JPPM (Jurnal Penelitian $\begin{array}{llllll}\text { dan } & \text { Pembelajaran } & \text { Matematika) } & \text { Vol. } & 11 & \text { No }\end{array}$ http://jurnal.untirta.ac.id/index.php/JPPM/article/view/3761

Sumadi Suryabrata. 2006. Psikologi Pendidikan. Jakarta: PT Raja Grafindo Persada.

Sumarmi. 2012. Model-Model Pembelajaran Geografi. Malang: Aditya Media.

Syaiful Sagala, 2005. Konsep dan Makna Pembelajaran Untuk Membantu Memecahkan Problematika Belajar dan Mengajar. Bandung: Alfabeta.

Taher, Achmad, Sugeng Utaya , dan Syamsul Bachri. 2019. Pengaruh Model Pembelajaran Kooperatif Tipe Group Investigation terhadap Hasil Belajar Geografi. urnal Pendidikan: Teori, Penelitian, dan Pengembangan Volume: 4 Nomor: 4 Bulan April Tahun 2019 Halaman: 456-461. Tersedia secara online http://journal.um.ac.id/index.php/jptpp/ EISSN: 2502-471X

Tohirin.2008. Psikologi Pembelajaran Pendidikan Agama Islam. Jakarta:Rineka Cipta.

Widiantara, Sedanayasa, dan Dibia. 2013. Pengaruh Model Pembelajaran Kooperatif Tipe Group Investigation (Gi) Berbantuan Media Realita Terhadap Hasil Belajar Matematika Siswa Kelas IV SD.

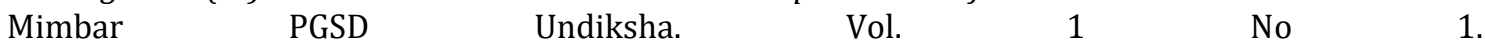
https://ejournal.undiksha.ac.id/index.php/JJPGSD/article/view/734/607 